\title{
Effect of Er:YAG laser-activated irrigation on dentine debris removal from different parts of the root canal system: An in vitro study
}

\section{Wpływ lasera Er:YAG aktywującego przepłukiwanie na usuwanie zębiny z różnych części kanału korzeniowego - badania in vitro}

\author{
Rami Zen Aldeen ${ }^{A-D}$, Ossama Aljabbann ${ }^{A, F}$, Hussam Milly ${ }^{C, D}$, Amro Allouch ${ }^{B, D}$, Omar Hamadah ${ }^{A, E, F}$
}

Faculty of Dentistry, Damascus University, Syria

A - research concept and design; $B$ - collection and/or assembly of data; $C$ - data analysis and interpretation;

$D$ - writing the article; $E$ - critical revision of the article; $F$ - final approval of the article

Address for correspondence

Omar Hamadah

E-mail: omar.hamadah@gmail.com

Funding sources

None declared

Conflict of interest

None declared

Received on December 9, 2017

Reviewed on February 9,2018

Accepted on February 23, 2018

\begin{abstract}
Background. There is insufficient information available in the literature about the efficacy of laser-activated irrigation (LAl) in removing dentine debris at different coronal-apical levels of the root canal system (RCS).

Objectives. To evaluate the efficacy of erbium (LAI) in removing dentine debris from different coronal-apical levels of the RCS when compared to passive ultrasonic irrigation (PUI) and conventional irrigation (CI).
\end{abstract}

Material and methods. Forty-five single-rooted human teeth were split longitudinally into halves. In each sample, a standardized groove was cut 2-6 mm from the apex along the canal wall of the $1^{\text {st }}$ half, and another standardized groove was cut $10-14 \mathrm{~mm}$ from the apex along the canal wall of the $2^{\text {nd }}$ half. Each groove was filled with dentine debris mixed with sodium hypochlorite ( $\mathrm{NaOCI}$ ) 5.25\%. The samples were assigned to 3 experimental groups according to the irrigant activation techniques ( $n=15)$; (a) $C$ l group, (b) PUI group and (c) LAl group. The amount of the remaining dentine debris was identified and scored using a stereomicroscope.

Results. Laser-activated irrigation removed significantly more debris than PUI and Cl systems. The efficacy of dentine debris removal was not affected by the root canal third within all groups.

Conclusions. Erbium LAl enhances dentine debris removal from the artificial irregularities in the RCS.

Key words: conventional irrigation, dentine debris removal, laser-activated irrigation, passive ultrasonic irrigation, root canal system

Słowa kluczowe: konwencjonalna irygacja, usuwanie zębiny, irygacja aktywowana wiązką laserową, pasywna irygacja za pomocą ultradźwięków, system kanału korzeniowego

DOI

$10.17219 / \mathrm{dmp} / 85709$

Copyright

○ 2018 by Wroclaw Medical University

and Polish Dental Society

This is an article distributed under the terms of the

Creative Commons Attribution Non-Commercial License

(http://creativecommons.org/licenses/by-nc-nd/4.0/) 
Chemo-mechanical preparation, including shaping and cleaning of the root canal system (RCS), is an essential step in successful endodontic treatment. ${ }^{1}$ Cleaning depends on using an irrigant solution to chemically dissolve the tissues and mechanically flush organic/inorganic debris out of the RCS. ${ }^{1}$ It has been suggested that the flushing action of the irrigant solution could be more critical than its dissolvent capability for complete debridement of the complex RCS. ${ }^{2}$ Conventional irrigation (CI) depends simply on a syringe and a needle to supply an irrigant solution to the root canal. In this protocol, the flushing action is not sufficient to remove organic/inorganic debris due to its limited distribution within the complex RCS. ${ }^{3,4}$ Therefore, several activation techniques have been suggested to increase the flushing action of irrigant solution and enhance its distribution within the root canal, including passive ultrasonic irrigation (PUI) and laser-activated irrigation (LAI). ${ }^{5}$

Passive ultrasonic irrigation depends on the acoustic streaming produced when an ultrasonically oscillating small file vibrates freely within the irrigant solution in the prepared root canal. ${ }^{6}$ Moreover, cavitation can occur during PUI. However, this specifically occurs at the tip of the oscillating file, requiring a large apical preparation and a high energy setting. ${ }^{7}$ Laser-activated irrigation improves the flushing action of the irrigant solution in the RCS, depending upon the cavitation effects, which includes the expansion and immediate implosion of the vapor bubble to induce a rapid movement of the intra-canal solution with profound shock waves and secondary cavitation bubbles ${ }^{8-10}$ It has been shown that erbium lasers, such as the erbium-doped yttrium aluminum garnet (Er:YAG) laser, exhibit the highest absorption in water, which promotes their use in the LAI technique. ${ }^{11}$

It has been suggested that erbium LAI may enhance debris removal from root canal irregularities. ${ }^{12-14}$ Laseractivated irrigation is performed using a plain fiber tip inserted within the root canal $5 \mathrm{~mm}$ away from the apex which, in turn, may exhibit undesirable side effects such as carbonization, cracking ${ }^{15}$ and apical extrusion. ${ }^{15,16}$ Therefore, using the fiber tip in the pulp chamber instead of inserting it within the canal is advocated. ${ }^{17-22}$ However, the use of the fiber tip in the pulp chamber without inserting it into the root canal may decrease the irrigant efficiency. Therefore, the objective of this study was to investigate the efficacy of LAI with a conical fiber tip (Xpulse ${ }^{\circledR} 400 / 14$; Fotona, Ljubljana, Slovenia) in dentine debris removal from different root canal levels when held in the pulp chamber, in comparison with both PUI and CI. The 2 null hypotheses investigated in this study were that LAI exhibited a similar efficiency in dentine debris removal to that of PUI and CI, and that the efficacy of dentine debris removal was not affected by different root canal levels.

\section{Material and methods}

\section{Sample preparation}

Forty-five caries-free, single-rooted human teeth, extracted from patients aged 18-30 years, were collected. The teeth were radiographed to verify the presence of only 1 canal without any resorptions or calcifications. Then, they were stored in saline solution at room temperature until use. The teeth were accessed and the working length (WL) was determined by inserting a size 10 file into the canal until the tip of the file was just visible at the apical foramen, and then deducting $1 \mathrm{~mm}$. Then, they were cut with a diamond disc under water coolant to standardize the working length at $19 \mathrm{~mm}$.

The canals were shaped with Protaper ${ }^{\circledR}$ universal rotary instruments (Dentsply Maillefer, Ballaigues, Switzerland) up to F2 (size 25) and irrigated with $2 \mathrm{~mL}$ of $5.25 \%$ sodium hypochlorite $(\mathrm{NaOCl})$ after each instrument was used. A diamond bur with a diameter of $2.3 \mathrm{~mm}$ was used to enlarge the coronal $3 \mathrm{~mm}$ of each tooth in order to simulate and standardize the pulp chamber. ${ }^{12}$

Each sample was partly embedded in a putty impression material $\left(\right.$ Zetaplus $^{\circledR}$; Zhermack, Badia Polesine, Italy) to obtain a matrix, allowing the reassembly of the tooth halves for irrigation test after splitting (Fig. 1A). ${ }^{3}$

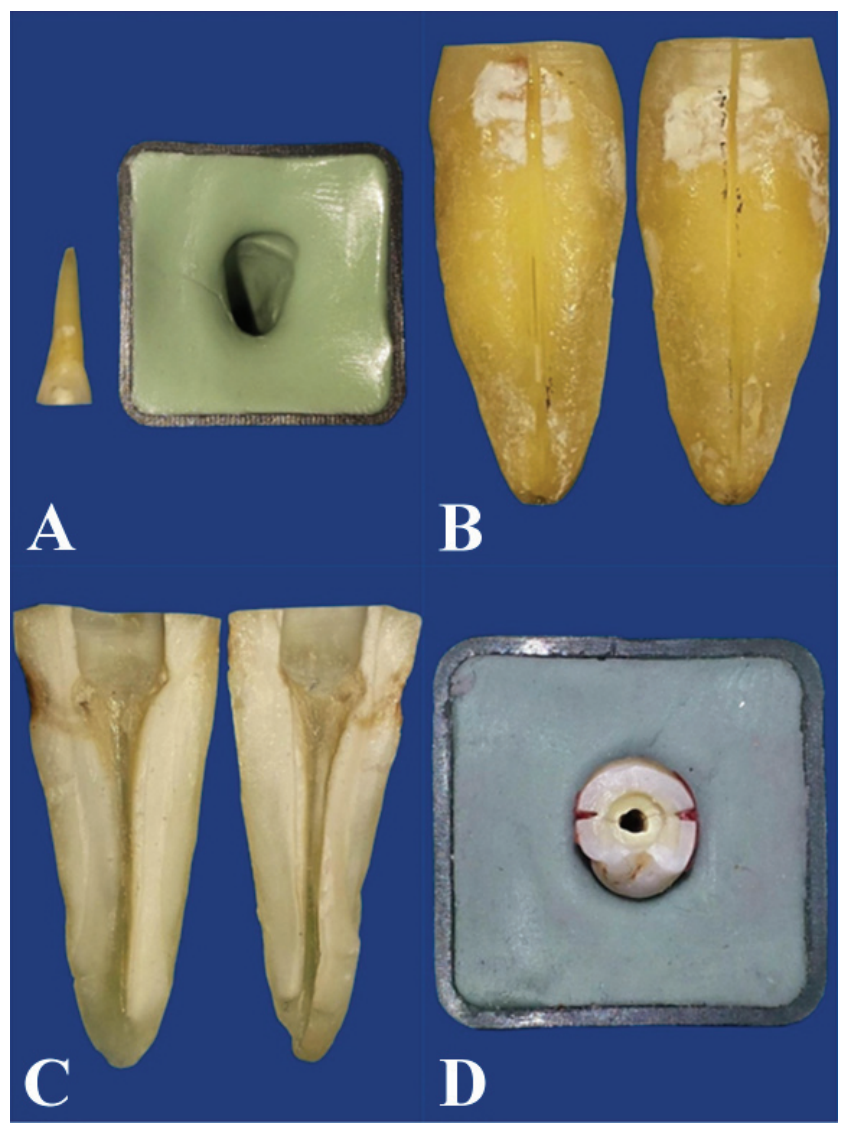

Fig. 1. A - a set matrix of putty impression material for tooth reassembling; B - grooves cut in the root surfaces; C - tooth was split into halves;

D - split tooth reassembled for irrigation tests 
Each tooth was grooved longitudinally with a diamond disc (Jota AG, Rüthi, Switzerland) along the outer surface of the root, avoiding penetration into the canal, to split it longitudinally into halves using a small chisel (Fig. 1B, 1C).

For each sample, a standardized groove ( $4 \mathrm{~mm}$ in length, $0.2 \mathrm{~mm}$ in width, $0.5 \mathrm{~mm}$ in depth) was cut 2-6 mm away from the apex on the canal wall of the $1^{\text {st }}$ half and a similar groove was cut 10-14 mm away from the apex on the canal wall of the $2^{\text {nd }}$ half (Fig. 2). This helps in stimulating the uninstrumented canal irregularities in the apical and coronal third, respectively. ${ }^{4,23}$ The dentine of other split teeth was grounded by round bur to produce dentine debris. Each groove was filled with this debris after mixing it with $5.25 \%$ $\mathrm{NaOCl} 5$ min before use. A digital baseline image for each half containing the groove was taken before the irrigation procedure using a digital camera (Nikon D80; Nikon Co, Tokyo, Japan) and a stereomicroscope (Meiji Techno D80; Saitama, Japan) at $\times 20$ magnification. The halves of each sample were reassembled using sticky wax and putty impression material (Fig. 1D).

\section{Irrigation protocols}

The specimens were randomly divided into 3 experimental groups $(n=15)$ according to the irrigant activation techniques; (a) CI group, (b) PUI group and (c) Er:YAG LAI group. The CI was performed with $5.25 \% \mathrm{NaOCl}$, delivered with a $10 \mathrm{~mL}$ syringe through a 30-gauge sidevented needle (NaviTip ${ }^{\circledR}$; Ultradent Products Inc, South Jordan, USA) at a rate of $0.1 \mathrm{~mL} / \mathrm{s}$. The needle was inserted $1 \mathrm{~mm}$ coronal to the working length and moved slowly up and down over a distance of $4 \mathrm{~mm}$ in the apical third of the canal. The open side of the needle always faced the canal half with the apical groove. ${ }^{3}$ A total of $6 \mathrm{~mL}$ of the solution was delivered over $60 \mathrm{~s}$.
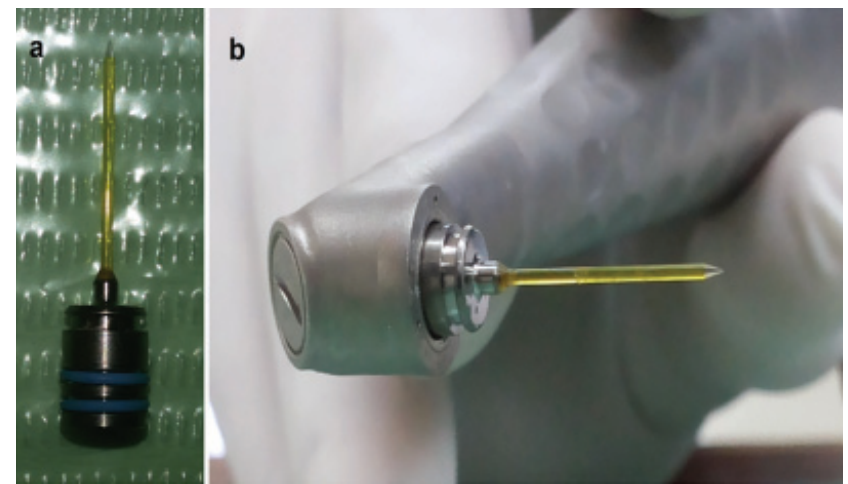

Fig. 3. A $14 \mathrm{~mm}$ long and conical 400 um fiber tip (Xpulse 400/14; Fotona Ljubljana, Slovenia) used in the study

Passive ultrasonic irrigation was conducted with a 15\# $\mathrm{K} / 21 \mathrm{~mm}$ file (Irri-Safe ${ }^{\circledR}$; Satelec, Acteon Group, Norwich, UK) driven by an ultrasonic device (Satelec). After the root canal was filled with $5.25 \% \mathrm{NaOCl}$, the ultrasonically-activated file was inserted $1 \mathrm{~mm}$ coronal to the WL and the ultrasonic activation cycle was done for $20 \mathrm{~s}$ at a power setting of $25 \%$. Then the canal was rinsed with $2 \mathrm{~mL}$ of $5.25 \% \mathrm{NaOCl}$ using a syringe and a needle, and the irrigant solution underwent a $2^{\text {nd }}$ ultrasonic activation cycle for $20 \mathrm{~s}$. This sequence was repeated 3 times, resulting in a total irrigation volume of $6 \mathrm{~mL}$ and total activation time of 1 min. $^{24}$

Laser-activated irrigation was carried out using an Er:YAG laser with a wavelength of $2.940 \mathrm{~nm}$ (LightWalker ${ }^{\circledR}$ AT; Fotona, Ljubljana, Slovenia). A $14 \mathrm{~mm}$ long and conical $400 \mu \mathrm{m}$ fiber tip (Xpulse 400/14; Fotona, Ljubljana, Slovenia) was utilized (Fig. 3). The laser operating parameters were $40 \mathrm{~mJ}$ per pulse, $20 \mathrm{~Hz}$ and $50 \mu$ s pulse duration. ${ }^{25}$ The water and air on the laser system were turned off. After the root canal was filled with
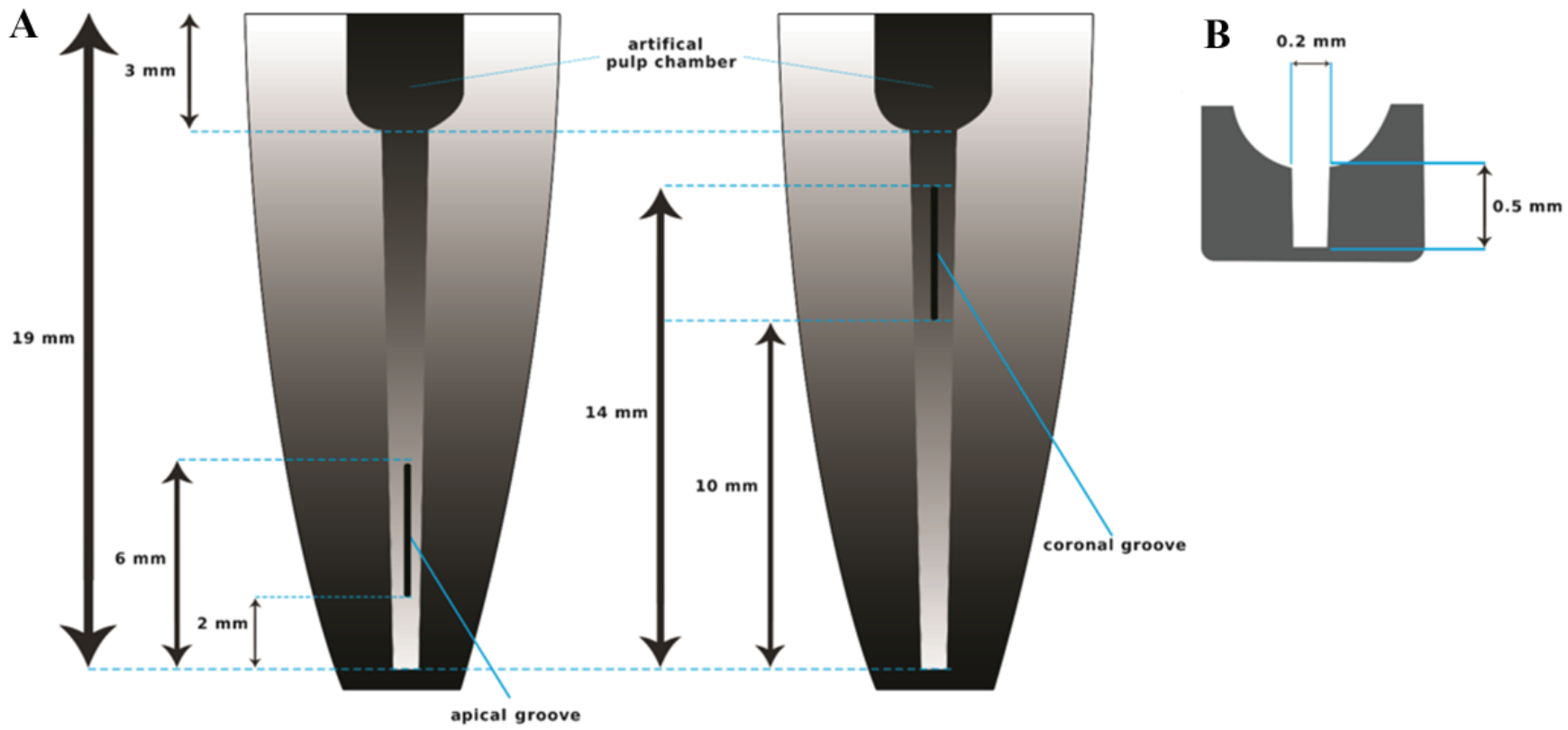

Fig. 2. Schematic representations of the "root canal-groove" model: A - the apical and coronal grooves; B - a cross section of the model 
$5.25 \% \mathrm{NaOCl}$, the fiber was placed into the artificial pulp chamber and a laser activation cycle was conducted for $30 \mathrm{~s}$ simultaneously with irrigation of $3 \mathrm{~mL} \mathrm{NaOCl}$ through the pulp chamber. After $30 \mathrm{~s}$ of resting time, another activation cycle was performed for another $30 \mathrm{~s}$, resulting in a total irrigation volume of $6 \mathrm{~mL}$ and total activation time of $1 \mathrm{~min}^{26}$

\section{Evaluation of dentine debris removal}

The canal was carefully dried with paper points and the root halves of each sample were separated to evaluate dentine debris removal within the grooves. A $2^{\text {nd }}$ digital image for each groove was taken at the same magnification as the baseline image. Two calibrated examiners, blinded to the experimental groups, assessed the presence/absence of dentine debris within the grooves. The reliability of the examiners was evaluated by repeating the assessment of the images after 1 week. A previously defined scoring system was used to evaluate the presence/absence of the dentine debris (Fig. 4): score 0 - the groove was empty; score 1 - less than half of the groove was filled with debris; score 2 - half or more of the groove was filled with debris; score 3 - the groove was completely filled with debris. ${ }^{4}$

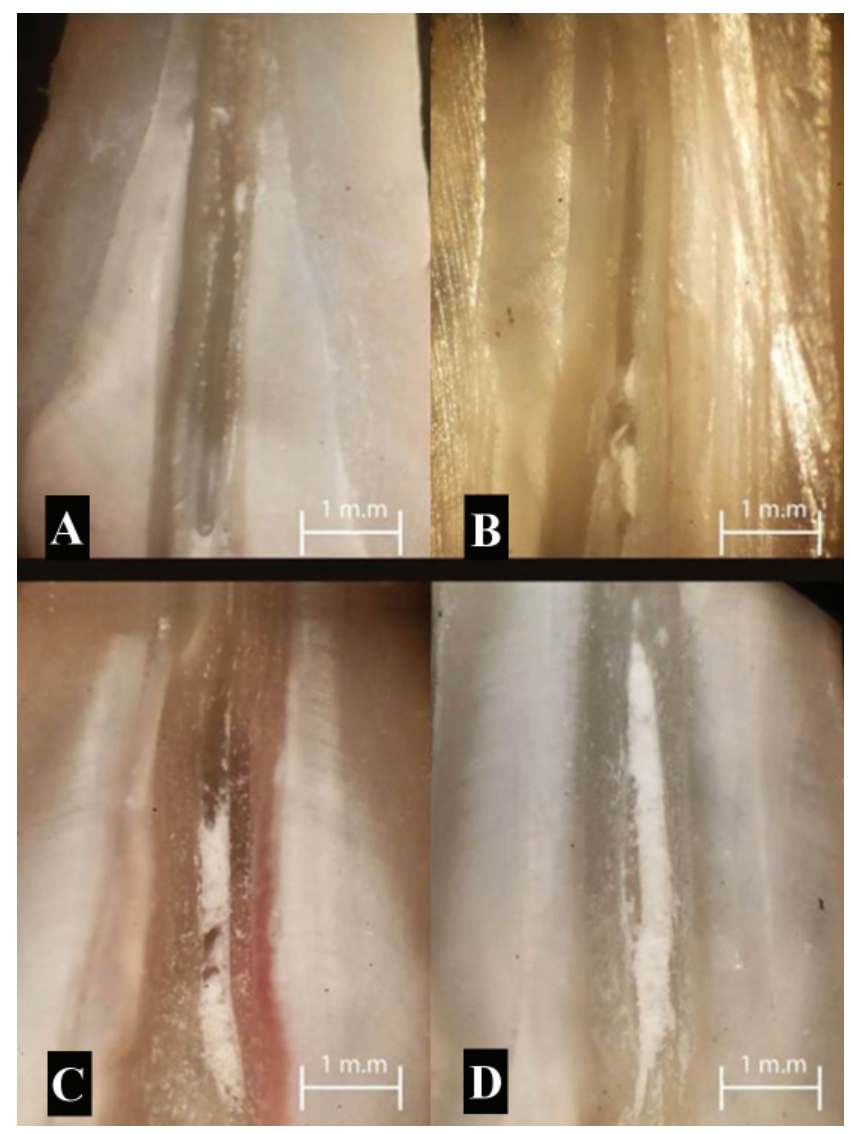

Fig. 4. Representative images of the grooves according to the dentine debris removal score: A) score 0 - the groove is empty; $\mathrm{B}$ ) score 1 - less than half of the groove is filled with debris; $C$ ) score 2 - more than half of the groove is filled with debris; D) score 3 - the groove is completely filled with debris
Table 1. Distribution of dentine debris scores for each irrigation technique

\begin{tabular}{|l|l|c|c|c|c|c|}
\multirow{2}{*}{$\begin{array}{l}\text { Irrigation } \\
\text { technique }\end{array}$} & $\begin{array}{l}\text { Location of } \\
\text { the groove }\end{array}$ & \multicolumn{5}{|c|}{ Debris score [\%] } \\
\cline { 3 - 7 } $\mathrm{Cl}$ & coronal & $0(0)$ & $1(6.7)$ & $7(46.7)$ & $7(46.7)$ & 15 \\
& apical & $0(0)$ & $5(33.3)$ & $6(40.0)$ & $4(26.7)$ & \\
\multirow{2}{*}{$\mathrm{PUI}$} & coronal & $6(40.0)$ & $8(53.5)$ & $1(6.7)$ & $0(0)$ & 15 \\
& apical & $6(40.0)$ & $7(46.7)$ & $2(13.3)$ & $0(0)$ & \\
\multirow{2}{*}{$\mathrm{LAl}$} & coronal & $12(80)$ & $3(20)$ & $0(0)$ & $0(0)$ & 15 \\
& apical & $12(80)$ & $2(13.3)$ & $1(6.7)$ & $0(0)$ & \\
\hline
\end{tabular}

Score 0 - the groove is empty. Score 1 - less than half of the groove is filled with debris. Score 2 - more than half of the groove is filled with debris. Score 3 - the groove is completely filled with debris. $\mathrm{LAI}$ - laser-activated irrigation; $\mathrm{n}$ - number;

$\mathrm{PUI}$ - passive ultrasound irrigation; $\mathrm{Cl}$ - conventional irrigation.

\section{Statistical analysis}

The intra-observer reproducibility and inter-observer agreement were tested using Cohen's kappa coefficient. Debris score data was analyzed using Kruskal-Wallis test and Mann-Whitney $U$ test. The effect of the location of the groove on the debris removal was analyzed using the Mann-Whitney U test. All statistical analyses were performed at the 95\% confidence level ( $p=0.05)$ using SPSS Statistics 17 software (IBM, SPSS Inc., Chicago, USA).

\section{Results}

Kappa value for the inter-observer agreement was 0.921, and for the intra-observer reproducibility the Kappa values were 0.984 and 0.968 for the $1^{\text {st }}$ and $2^{\text {nd }}$ observer, respectively. Table 1 presents the debris score values according to the experimental groups in the coronal and apical grooves. A score of 3 was observed only within the CI group (7 grooves in the coronal group and 4 halves in the apical group). The highest values for score 0 were presented in the LAI group with 24 out of 30 halves.

There were significant differences between the 3 experimental groups in both apical and coronal grooves (Kruskal-Wallis test $\mathrm{p}<0.001$ ). Table 2 shows the results of the Mann-Whitney $U$ test comparing debris scores

Table 2. Results of Mann-Whitney $U$ test comparing debris scores between groups in both apical and coronal grooves. A p-value $\leq 0.05$ was considered statistically significant

\begin{tabular}{|l|c|c|c|}
\hline $\begin{array}{l}\text { Location } \\
\text { of the groove }\end{array}$ & Comparison & $\begin{array}{c}\text { Mann-Whitney } \\
\text { U test }\end{array}$ & p-value \\
\hline \multirow{3}{*}{ Apical } & LAI vs PUI & 69.0 & $0.038^{*}$ \\
& LAI vs Cl & 13.0 & $<0.001^{*}$ \\
& PUI vs Cl & 33.5 & $0.001^{*}$ \\
Coronal & LAI vs PUI & 66.0 & $0.025^{*}$ \\
& LAI vs Cl & 1.5 & $<0.001^{*}$ \\
\hline
\end{tabular}

* statistically significant values; LAI - laser-activated irrigation; PUI - passive ultrasound irrigation; CI - conventional irrigation. 
Table 3. Results of the Mann-Whitney $U$ test comparing the debris scores between the apical and coronal grooves within each group. A p-value $\leq 0.05$ was considered statistically significant

\begin{tabular}{|l|c|c|c|}
\hline Comparison & Irrigation technique & Mann-Whitney U test & p-value \\
\hline \multirow{2}{*}{ Apical vs } & LAl & 111.0 & 0.929 \\
coronal & PUI & 108.0 & 0.836 \\
& $\mathrm{Cl}$ & 75.5 & 0.098 \\
\hline
\end{tabular}

LAI - laser-activated irrigation; PUI - passive ultrasound irrigation; $\mathrm{Cl}$ - conventional irrigation

between groups. In the apical groove, LAI removed significantly more dentine debris than PUI $(\mathrm{p}=0.038)$ and $\mathrm{CI}(\mathrm{p}<0.001)$. Passive ultrasonic irrigation removed significantly more dentine debris than CI $(\mathrm{p}=0.001)$. In the coronal groove, LAI was significantly better than PUI $(\mathrm{p}=0.025)$ and CI $(\mathrm{p}<0.001)$ in removing dentine debris. Passive ultrasonic irrigation was more efficient than CI $(\mathrm{p}<0.001)$ in removing dentine debris. The MannWhitney $U$ test revealed that there was no significant difference on the debris removal score according to the location of the grooves within the same experimental irrigation group $(\mathrm{p}>0.05)$ (Table 3$)$.

\section{Discussion}

This study showed that CI was significantly less effective in dentine debris removal when compared to the LAI and PUI techniques, which is in accordance with previous studies. ${ }^{23}$ Conventional irrigation exhibited a limited distribution and a weak stream action and therefore, its flushing action was not sufficient to remove organic and inorganic debris. ${ }^{3,4}$ The findings of this study indicate that LAI was significantly more efficient in dentine debris removal in comparison to PUI, in agreement with the findings of the previous studies which used a plain fiber tip within the root canal. ${ }^{12-14}$ In this study, however, a conical fiber tip was used in the pulp chamber without inserting it in the canal. This may be explained by the fact that the conical tip was able to transfer the laser energy along the root canal walls. ${ }^{27}$

The statistical analysis shows that LAI was significantly better than PUI at removing dentine debris from both apical and coronal grooves, which is compatible with the findings of a previous study that used a modified conical fiber tip - photon-initiated photoacoustic streaming (PIPS) tip - in the pulp chamber without inserting it within the root canal to remove dentine debris and antibiotic paste. ${ }^{28,29}$ The stronger mechanical effect and better fluid movement of LAI resulting from the bubbles' impulsive nature induced by laser energy improve the dentine debris removal. ${ }^{13,20,30}$ The term PIPS describes the interaction of laser energy with irrigant solutions when using a special laser fiber (the conical end and distal 3-mm without coating), which differs from the fiber used in the present study, a conical fiber tip (Xpulse; Fotona, Ljubljana, Slove- nia). The use of this fiber design with a minimal ablative energy of $40 \mathrm{~mJ}$ permitted efficient dentine debris removal with consideration of the safety of the procedure. ${ }^{25}$

The findings concerning the efficacy of LAI in dentine debris removal according to the root canal thirds are compatible with a previous study evaluating the efficacy of LAI in removing antibiotic paste from artificial coronal and apical grooves. ${ }^{29}$ However, Meire et al. claimed that the removal of the dentine debris was promoted when the fiber tip was held next to the apical groove rather than placed in the canal entrance or the pulp chamber. ${ }^{25}$ In the present study, $\mathrm{NaOCl}$ was used as an irrigant solution, which may enhance the amount of secondary activation bubbles, improving the cleaning of the apical part, whilst Meire et al. used water as an irrigant solution. ${ }^{25}$ In addition, the activation time was longer in this study (60 s), which may correlate with better dentine debris removal.

The root canal-groove model used in the present study ensures the standardization of the location and size of the grooves, making possible consistent evaluation with high reproducibility for the remaining debris. ${ }^{4,23}$ However, this standardized groove method does not perfectly simulate an in vivo irregularity and the complex anatomy of the natural RCS, exhibiting a limitation of this study. Therefore, further studies are still required to evaluate the cleaning efficiency of LAI in vivo.

\section{Conclusion}

Laser-activated irrigation was significantly more efficient in dentine debris removal when compared to $\mathrm{CI}$ and PUI. Therefore, the $1^{\text {st }}$ null hypothesis was rejected. The $2^{\text {nd }}$ null hypothesis was accepted, as the efficacy of LAI in removing dentine debris was not affected by the root canal thirds. Thus, Er:YAG LAI enhances dentine debris removal from artificial irregularities in the root canal walls.

\section{References}

1. Haapasalo M, Endal U, Zandi H, Coil JM. Eradication of endodontic infection by instrumentation and irrigation solutions. Endod Topics. 2005;10:77-102.

2. Gutarts R, Nusstein J, Reader A, Beck M. In vivo debridement efficacy of ultrasonic irrigation following hand-rotary instrumentation in human mandibular molars. J Endod. 2005;31:166-170.

3. Huang TY, Gulabivala K, Ng YL. A biomolecular film ex vivo model to evaluate the influence of canal dimensions and irrigation variables on the efficacy of irrigation. Int Endod J. 2008;41:60-71.

4. Lee SJ, Wu MK, Wesselink P. The effectiveness of syringe irrigation and ultrasonics to remove debris from simulated irregularities within prepared root canal walls. Int Endod J. 2004;37:672-678.

5. Gu L-S, Kim JR, Ling J, et al. Review of contemporary irrigant agitation techniques and devices. J Endod. 2009;35:791-804.

6. Van der Sluis LWM, Versluis M, Wu MK, Wesselink PR. Passive ultrasonic irrigation of the root canal: $A$ review of the literature. Int Endod J. 2007:40:415-426.

7. Jiang L-M, Verhaagen B, Versluis $M$, et al. The influence of the ultrasonic intensity on the cleaning efficacy of passive ultrasonic irrigation. J Endod. 2011;37:688-692. 
8. Blanken JW, Verdaasdonk RM. Cavitation as a working mechanism of the Er, Cr: YSGG laser in endodontics: A visualization study. JOLA. 2007;7:97-106.

9. Blanken J, De Moor RJG, Meire M, Verdaasdonk R. Laser-induced explosive vapor and cavitation resulting in effective irrigation of the root canal. Part 1: A visualization study. Lasers Surg Med. 2009;41:514-519.

10. Matsumoto $H$, Yoshimine $Y$, Akamine A. Visualization of irrigant flow and cavitation induced by Er: YAG laser within a root canal model. J Endod. 2011;37:839-843.

11. De Moor R, Torbeyns D, Meire M. Lasers in endodontics. Part 2: Root canal wall cleanliness and modification. ENDO. 2009;3:19-33.

12. De Moor RJG, Blanken J, Meire M, Verdaasdonk R. Laser-induced explosive vapor and cavitation resulting in effective irrigation of the root canal. Part 2: Evaluation of the efficacy. Lasers Surg Med. 2009;41:520-523.

13. De Groot $S$, Verhaagen B, Versluis $M$, et al. Laser-activated irrigation within root canals: Cleaning efficacy and flow visualization. Int Endod J. 2009;42:1077-1083.

14. De Moor RJ, Meire M, Goharkhay K, et al. Efficacy of ultrasonic versus laser-activated irrigation to remove artificially-placed dentin debris plugs. J Endod. 2010;36:1580-1583.

15. Yamazaki R, Goya C, Yu D-G, Kimura Y, Matsumoto K. Effects of erbium, chromium: YSGG laser irradiation on root canal walls: A scanning electron microscopic and thermographic study. J Endod. 2001;27:9-12.

16. George R, Walsh LJ. Apical extrusion of root canal irrigants when using Er: YAG and Er, Cr: YSGG lasers with optical fibers: An in vitro dye study. J Endod. 2008;34:706-708.

17. DiVito E, Peters O, Olivi G. Effectiveness of the erbium: YAG laser and new design radial and stripped tips in removing the smear layer after root canal instrumentation. Lasers Med Sci. 2012;27:273-280.

18. Peeters $\mathrm{HH}$, Suardita K. Efficacy of smear layer removal at the root tip by using ethylenediaminetetraacetic acid and erbium, chromium: Yttrium, scandium, gallium garnet laser. J Endod. 2011;37:1585-1589.

19. Peeters $\mathrm{HH}$, Gutknecht N. Efficacy of laser-driven irrigation versus ultrasonic in removing an airlock from the apical third of a narrow root canal. Aust Endod J. 2014;40:47-53.

20. Koch JD, Jaramillo DE, DiVito E, Peters OA. Irrigant flow during photon-induced photoacoustic streaming (PIPS) using Particle Image Velocimetry (PIV). Clin Oral Investig. 2016;20:381-386.

21. Arslan $H, A$ kcay $M$, Ertas $H$, et al. Effect of PIPS technique at different power settings on irrigating solution extrusion. Lasers Med Sci. 2015;30:1641-1645.

22. Peeters HH, Mooduto L. Radiographic examination of apical extrusion of root canal irrigants during cavitation induced by Er, Cr: YSGG laser irradiation: An in vivo study. Clin Oral Investig. 2013;17:2105-2112.

23. Rödig T, Bozkurt M, Konietschke F, Hülsmann M. Comparison of the vibringe system with syringe and passive ultrasonic irrigation in removing debris from simulated root canal irregularities. J Endod. 2010;36:1410-1413.

24. van der Sluis LW, Vogels MP, Verhaagen B, et al. Study on the influence of refreshment/activation cycles and irrigants on mechanical cleaning efficiency during ultrasonic activation of the irrigant. J Endod. 2010;36(4):737-740.

25. Meire MA, Havelaerts S, De Moor RJ. Influence of lasing parameters on the cleaning efficacy of laser-activated irrigation with pulsed erbium lasers. Lasers Med Sci. 2016;31:653-658.

26. Macedo $\mathrm{R}$, Wesselink $\mathrm{P}$, Zaccheo $\mathrm{F}$, et al. Reaction rate of $\mathrm{NaOCl}$ in contact with bovine dentine: Effect of activation, exposure time, concentration and pH. Int Endod J. 2010;43:1108-1115.

27. George R, Meyers IA, Walsh LJ. Laser activation of endodontic irrigants with improved conical laser fiber tips for removing smear layer in the apical third of the root canal. J Endod. 2008;34:1524-1527.

28. Arslan H, Capar I, Saygili G, et al. Effect of photon-initiated photoacoustic streaming on removal of apically placed dentinal debris. Int Endod J. 2014;47:1072-1077.

29. Arslan H, Akcay M, Capar ID, et al. Efficacy of needle irrigation, EndoActivator, and photon-initiated photoacoustic streaming technique on removal of double and triple antibiotic pastes. J Endod. 2014;40:1439-1442.

30. De Meyer S, Meire M, Coenye T, De Moor R. Effect of laser-activated irrigation on biofilms in artificial root canals. Int Endod J. 2016;50:472-479. 